\title{
超微粒子シリカフュームのコンクリートへの利用
}

\section{Use of Condensed Silica Fume in Concrete}

米倉 亜州夫*

Asuo YONEKURA

Key Words : Concrete, Condensed Silica Fume, Fine Particle, Silica Fume, Pore Structure

1.はじめに

シリカフュームは, フェロシリコン*1)やフェロシリ コン合金の製造時に発生する廃ガスを集塵することに よって得られる超微粒子の産業副産物であるが, フェ ロシリコン等を製造するのに大量の電力を必要とする ため, フライアッシュや高炬スラグ微粉末等のように 大量かつ安価に供給されるというあのではない。しか し，シリカフュームをコンクリートに混和した場合， 材料分離に対する抵抗性, 強度発現性, 水密性, 耐久 性等が著しく改善できることが明らかにされるにつれ $\tau^{1-5)}$, シリカフュームの需要が急速に拡大しつつお る。

シリカフュームを用いたコンクリートの研究は, 1970 年代からノルウェー, デンマーク等で始められ たが，現在では世界各国で行われており，国際会議が

平成元年 2 月 13 日受付

*広島大学工学部第 4 類 (采 724 東広島市西条町下見)

TEL $0824-22-7111$ 内線 3824

〈著者紹介〉

昭和 42 年広島大学大学院工学研究科修了後 1 年間阪神高速道路公団 勤務。昭和 $43 \sim 49$ 年広島大学助手

昭和50 53年東京工業大学助手を経て昭和 53 年 4 月より，広島大学 講師，昭和57年より広島大学助教授、工学博士。

専門 : コンクリート工学 (土木工学)

コンクリートの乾燥収縮およびクリープ, シリカフュームや 高炬スラグ微粉末を用いたコンクリート，流動コンクリート の研究。鉄筋コンクリートおよびプレストレストコンクリー トのねじり強さの研究等を行っている。

*1)フェロシリコン (ferrosilicon)：けい素鉄のととで鉄とけい素 の合金で脆く，銀白色の光沢を示す。鋳鉄や製鋼におりる脱酸 剂として広く使われている。バネなど硬くて強いけい素鋼の原 料として不可欠である。
1983 年にカナダ6)で, 1986 年にはスペイン7)で開催 されており，貴重な研究成果が報告されている ${ }^{8,9)}$ 。ま た 1989 年 6 月にあ,ノルウェーで第 3 回国際会議が開 催される予定である。我が国であ，乙の10年程の間に 多数の研究発表がなされている。

2. シリカフューム

\section{1 製造方法および生産}

シリコンやフェロシリコンは, 原料としてのけい石, 高純度の石英および鉄くずと，還元剤としてのカーボ ン電極および石炭を電気炉で $2000^{\circ} \mathrm{C}$ 亿近い高温まで上 昇させて製造されるが，乙の際発生する中間生成物と しての $\mathrm{SiO}$ がガス化して一部が空中に飛散し, 排気ダ クトの中で酸化され, $\mathrm{SiO}_{2}$ として集塵機で回収され る ${ }^{10,11)}$ 。そのため, $\mathrm{SiO}_{2}$ を主成分とする超微粒子で 完全に球形のあのが得られるが，乙れがシリカフュー ムである。

世界の生産量は 1981 年度で約 100 万トンと推定され ているが ${ }^{1,3)}$ ，主な生産国は，アメリカ，ソ連，安価な 水力発電による電力が豊富に得られるノルウェ一や力 ナダである。我が国は電力が高価であるため, 1983年 の生産量は約 3 万トンで, 今後, 量的な伸びはあまり 期待できない。現に，ノルウェ一等からの輸入が増大 しつつある。

\section{2 シリカフュームの物理的性犋および化学成分}

（1）色灰色であるが，炭素含有量によって，白 色系のあのから黒色系のあのまである。水を加える之 粉末のときより相当黒くなるが, 硬化したコンクリー トの色は, シリカフューム無混入の場合よりやや青黒 い程度で大差ない。

（2）比重およびかさ密度＼cjkstart比重は 2.1 2.2 程度の 
あのが多い。かさ密度は $250 \sim 300 \mathrm{~kg} / \mathrm{m}^{3}$ であり ${ }^{1)}$, 普通ポルトランドセメントの約 $1200 \mathrm{~kg} / \mathrm{m}^{3}$ と比較し て著しく小さい。したがって, 輸送時に多くの容積を 必要とし, 不経済になる。そてで, 顆粒状にしたり, 水を加えてスラリー状にして運搬する方法も一部で採 用されている。

（3）粉末度 シリカフュームは, 図 1 亿示すよう に, 球形の超微粒子で, 図 2 亿示すように, 粒の大き さは $1 \mu \mathrm{m}$ 以下で, 質量中位径は $0.1 \mu \mathrm{m}$ 程度であり ${ }^{1)}$, 比表面積は, 窒素吸着法による值では 15,000 25,000 $\mathrm{m}^{2} / \mathrm{kg}$, 平均的には約 $20,000 \mathrm{~m}^{2} / \mathrm{kg} ゙{ }^{11)}$, たばての煙 (比表面積約 $10,000 \mathrm{~m}^{2} / \mathrm{kg}$ ) より細かい1)。普通ポルト ランドセメントの場合は, 粒径が $1 \sim 100 \mu \mathrm{m}$, 質量中 位径が $20 \sim 30 \mu \mathrm{m}$, 比表面積が $300 \sim 400 \mathrm{~m}^{2} / \mathrm{kg}$ (ブ レーン值）であるので, シリカフュームがいかに超微 粒子であるかが分かる。

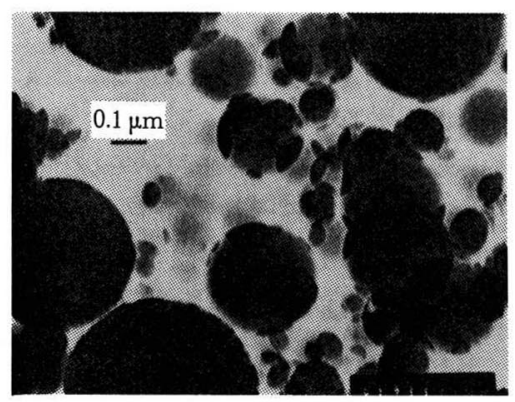

図 1 シリカフュームの電子顕微鏡透過写真 5 )

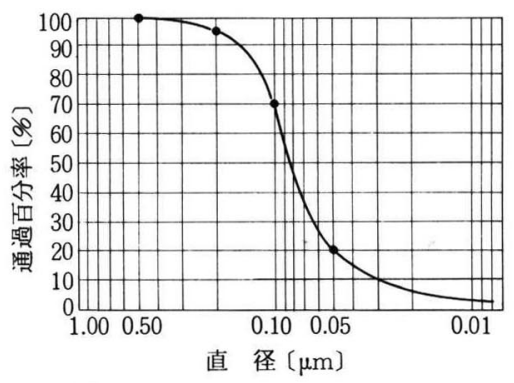

図 2 シリカフュームの粒度分布1)

表 1 シリカフュームの化学成分 ${ }^{2)}$

(単位: \%)

\begin{tabular}{|c|c|c|c|c|c|c|}
\hline \multirow{2}{*}{$\begin{array}{l}\text { 化 } \\
\text { 学 } \\
\text { 成 } \\
\text { 分 }\end{array}$} & \multirow{2}{*}{$\begin{array}{l}\text { オラ } \\
1 \text { リ } \\
\text { スア } \\
\text { 卜 }\end{array}$} & \multicolumn{2}{|c|}{$\begin{array}{l}\text { アメリカと } \\
\text { カナダ15工場 }\end{array}$} & \multicolumn{2}{|c|}{ 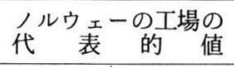 } & \multirow{2}{*}{ 規格値* } \\
\hline & & 最小値 & 最大値 & $\begin{array}{l}\text { フェェロ } \\
\text { シリコン }\end{array}$ & $\begin{array}{l}\text { シリコン } \\
\text { メタル }\end{array}$ & \\
\hline $\mathrm{SiO}_{2}$ & 88.60 & 63.30 & 96.00 & $86 \sim 92$ & $94 \sim 98$ & $87 \sim 94$ \\
\hline $\mathrm{Al}_{2} \mathrm{O}_{3}$ & 2.44 & 0.10 & 5.45 & $0.2 \sim 0.6$ & $0.10 \sim 0.40$ & $0.6 \sim 1.4$ \\
\hline $\mathrm{Fe}_{2} \mathrm{O}_{3}$ & 2.56 & 0.10 & 12.20 & $0.1 \sim 1.0$ & $0.02 \sim 0.15$ & $0.5 \sim 2.0$ \\
\hline $\mathrm{C}$ & 3.00 & 1.75 & 10.00 & $0.8 \sim 3.0$ & $0.2 \sim 2.0$ & $0.8 \sim 2.0$ \\
\hline
\end{tabular}

*ノルウェーNorcem 社で市販されている製品
（4）化学成分 表 1 に示すように, シリカフュー ムの化学成分は, 使用する原料, 主製品の種類, 国に よって,また製造方法によって種々に変化する。しか し, 化学成分の大部分を占める $\mathrm{SiO}_{2}$ は非晶質のものが ほとんよ゙であるが (10), 非晶質の $\mathrm{SiO}_{2}$ はアルカリ溶液中 で可溶性となり，乙の $\mathrm{SiO}_{2}$ が多いものほど反応性が高 くなる。

\section{3. シリカフュームを用いたコンクリートの特性}

\section{1 フレッシュコンクリート(まだ固まらないコン} クリート)の性質

（1）単位水量および流動性図３亿示すように, シリカフュームをセメントの一部と置換して高性能減 水剤（コンクリートの流動性を著しく大きくする混和 剤）を使用しない場合，所要の流動性を得るに必要な 単位水量はシリカフューム置換率を増大させるほど大 きくしなければならないが, 高性能減水剤を使用すれ ば，単位水量の増大をほとんど防止できる ${ }^{13)}$ 。したが って, シリカフュームを用いる場合には, 高性能減水 剂との併用が不可欠である。Bache ${ }^{12}$ は, 水セメント 比( $\mathrm{W} / \mathrm{C}$ : 重量比) $0.13 \sim 0.18$ のルタルに大量の高 性能減水剂を用いて練りまぜた場合, モルタルはパサ パサで乾燥したように見えるが，乙れに乾燥したシリ カフュームをセメント重量の25\%加えて再摚拌すると, 数分の練りまぜ時間で粘性流体状のモルタルが得られ, 少し振動を加えながら流し込むと容易に締固めるとと ができることを報告している。乙れは, 図4 亿示され るように, シリカフュームがセメント粒子の間に入り 込んでボールベアリングの作用をすることや, セメン 卜粒子で囲まれて水で満たされた空隙に, シリカフュ 一ムの超微粒子が侵入して空隙を充埧し, 水を追い出

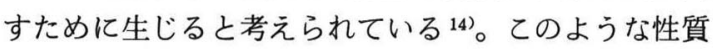
を, 高密度充填性も含めてマイクロフィラー効果と称

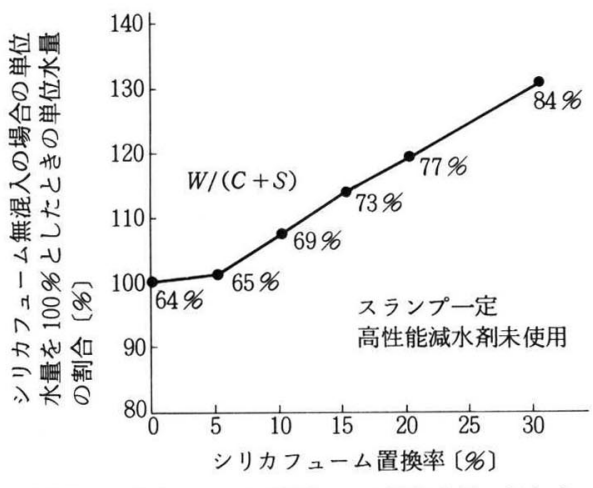

図 3 シリカフューム使用による単位水量の増加1) 


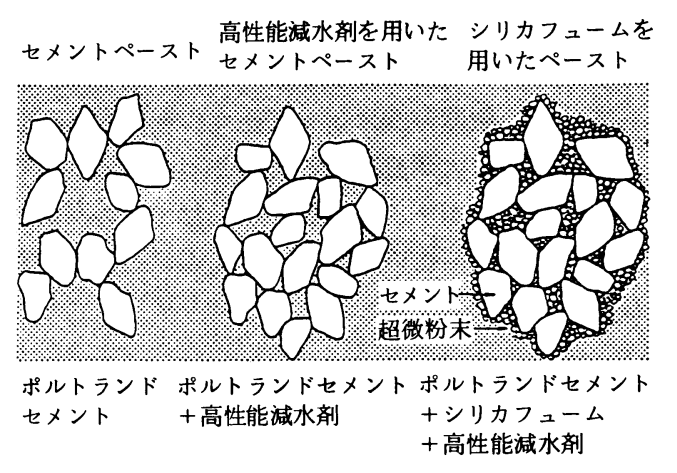

図4まだ固まらないコンクリート中のペースト構造 ${ }^{12)}$

している。水結合材比 $\mathrm{W} /(\mathrm{C}+\mathrm{Si})$ (コンクリート $1 \mathrm{~m}^{3}$ 当りの単位水量, 単位セメント量および単位シリカフ ュームの重量を各々 $\mathrm{W}, \mathrm{C}$ および $\mathrm{Si}$ で表示)が 0.3 以上 程度の場合は図 3 亿示すようにシリカフューム置換率 の増大に伴って流動性が小さくなるので水量を増大さ せる必要があったが, $\mathrm{W} /(\mathrm{C}+\mathrm{S})$ が 0.2 程度以下の場 合は, 高性能減水剤を多量混入しただけでは流動性が 得られないのに, てれに超微粒子を多量混入するとと により流動性が逆に大きくなるということは驚異に值 するととである。蔉ら ${ }^{15)}$ は, 図 5 に示すように, 粒径 の大きさによってマイクロフィラー効果が異なるか否 かについて, フライアッシュおよび高炬スラグ微粉末 を粉砕分級して, 種々の粒径のあのを製造し, モル夕 ルとした場合の流動性をシリカフュームの場合と比較 している。乙てで, テーブルフローとは, モルタルの 流動性を示す一つの指標で, フローテーブル上でコー ンにモルタルを詰め,コーンを取り去った後に、テー ブルに打撃を15回加えたときのモルタルのひろがり (直径)であり, 值が大きいほどやわらかいととを示す。 粒径が $1 \mu \mathrm{m}$ 以下のあのとセメントとを $1: 4$ の割合で 用いたモルタルは, チキソトロピックな性質を示し, 低水セメント比の場合でも, 粒径が小さいほど流動性

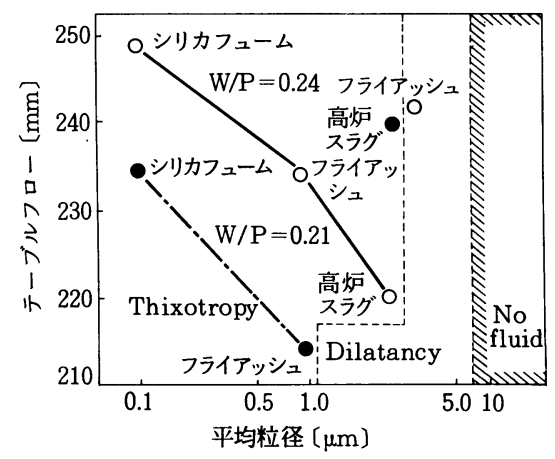

図 5 DSP モルタルの流動性に及ぼす超微粉の影传5)
は向上する。しかし, 数 $\mu \mathrm{m}$ の粒子をセメントと組み 合わせた場合には, 水結合材比が小さい場合には, 流動性は改善されず, ダイラタンシーな流動特性を示 し, 低水結合材比ではミキサーでの練り混ぜが困難に なると述べている。

（2）空気量寒冷地におけるコンクリートの凍結・ 融解のくり返しによるコンクリートの劣化を防ぐため, またはコンクリートの流動性を増大させるために $\mathrm{AE}$ 剤(Air Entraining Ajent)という混和剂を用いて微細 な空気泡をコンクリート中に連行する。てれがコンク リートの空気量であるが, シリカフュームは, 比表面 積が著しく大きいてと, 未燃の炭素を含有しているて となどのため, 空気がコンクリート中に連行されにく い。所要の空気量を得るためには, 通常のコンクリー トの場合に比べ, シリカフューム置換率が20\%で, 単 位水量を増大させずに高性能減水剂によってスランプ*2) を一定にしたコンクリートでは, $\mathrm{AE}$ 剂の使用量が4〜 5 倍に達したという報告がある ${ }^{1}$ 。

（3）ブリージング, 材料分離抵抗性, 施工性コ ンクリートは, 水, セメント, 砂, 砂利等を混合した あのであるから,コンクリート打込み後比重の小さい 水は上方向に浮きあがろうとする性質があり, てのよ うにしてコンクリート上面にでてきた水をブリージン グ水, このような現象をブリージングと称し, 材料分 離の一つと考えられている。ブリージングによって, コンクリートの強度低下, 透水性の增大, 耐久性の低 下, 沈下ひびわれの発生等, 悪影響を生じることが多 いが, シリカフュームをセメントの一部と置換するて とによって, ての置換率が高いほど, ブリージングは 著しく滅少し, 置換率が10\%以上ではほとんど生じな

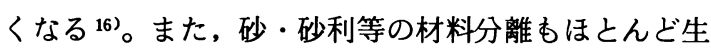

*2) スランプ: コンクリートのコンシステンシーの測定方法の一つ で,スランプ試験において, 図*1に示すコーンにコンクリー トを 3 層につめ, コーンを静かに引き上げたとき, コンクリー 卜頂面のさがりをスランプと称し，スランプが大きいほどやわ らかいととを示す。コンクリートに変形を起とさせる力(自重) と,コンクリートの変形に対する抵抗力とがつり合ったときに 静止する。レオロジーの降伏値に相当する。

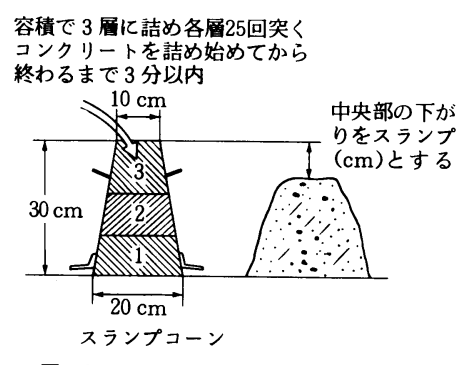

図*1 コンクリートのスランブ試験方法 
じない。乙れは, シリカフューム置換率が増大すると 粘性が著しく增大するととと, セメント粒子間に存在 するシリカフュームの粒子と, 水とセメントとの水和 反応によって生じた水酸化カルシウムとがきわめて短 時間に反応して, 水和生成物であるゲル層を作り, て のゲル層がブリージング水の移動を抑制するととによ

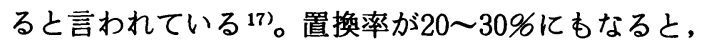
水道水を直接コンクリートに当ててあ分離しにくいの で, 水中コンクリートとして利用するてとも可能であ る。

シリカフュームコンクリートは粘性が高いため, 締 固めを十分行わないと，大きな空隙が残留しやすい。 バイブレータによって, 過振動気味に締固めをしても, 材料分離はほとんど生じない。また，表面がべタべ夕 しているので, 型わくバイブレータで振動させながら 表面仕上げをするとよい。炭素瀻維コンクリートにお いては, 繊維がコンクリート中で分散しにくく, 繊維 の固まりであるファイバーボールが生じやすいが, シ リカフュームを10〜20\%置換するてとによって，ファ イバーボールの発生を抑制し, 炭素瀻維を均一に分散 させることができる。

\section{2 水和および水和熱}

シリカフュームのポゾラン反応性（セメントと水と の水和生成物である水酸化カルシウム $\mathrm{Ca}(\mathrm{OH})_{2}$ 之徐々 に化合し, シリケート水和物 C-S - H を生成する反 応）は, フライアッシュよりあ高く, 強度発現への寄 与が大きい11)。シリカフュームは, その一部が $\mathrm{Ca}(\mathrm{OH})_{2}$ 溶液に 5 1 15 分というごく短時間に溶解し, シリカフ 一ム粒子の表面にシリカ $\left(\mathrm{SiO}_{2}\right)$ に富むゲル層を析出し, このゲル層は塊状になり， C-S - Hを生成する ${ }^{18,19) 。 ~}$ この C-S - Hは非常に緻密であり, 骨材との付着も良 く, 強度発現に寄与する。

シリカフュームを添加した場合の水和熱は, 普通ポ ルトランドセメントの場合より, フライアッシュ, 高 炬スラグ微粉末等の場合と同様, 減少する。しかし, リグニンスルフォン酸塩の減水剂を用いた場合, 図 6 に示すように, シリカフュームを混入した場合のほう が水和初期の発熱が促進されている ${ }^{20) 。 ~}$

\section{3 硬化したコンクリートの性質}

(1) 細孔構造 セメントペーストの細孔構造は硬 化体の諸性状に大きな影響を及ぼすので, シリカフュ 一ムを用いた場合の細孔構造について, まず第一に述 ベ，その後で硬化コンクリートの性質について述べる。 図 7 に示すように, Mehta ${ }^{21)}$ は, 水銀圧入法により細 孔径分布を測定している。曲線の傾きが大きい所ほど,
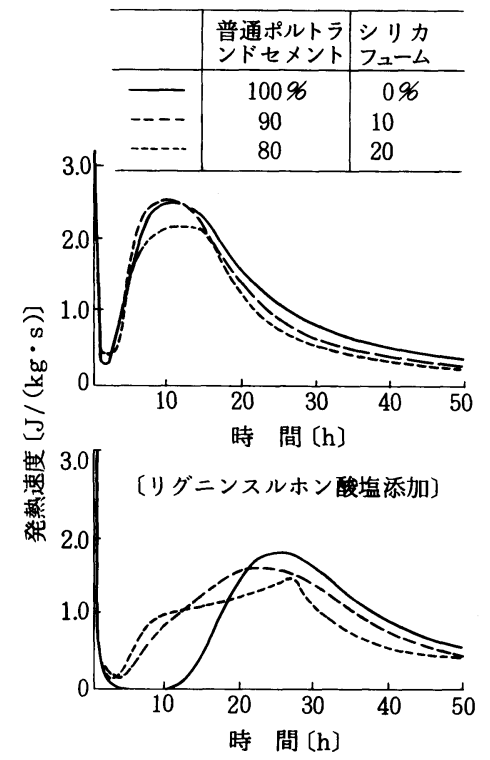

図 6 水和発生熱速度曲線 ${ }^{20}$

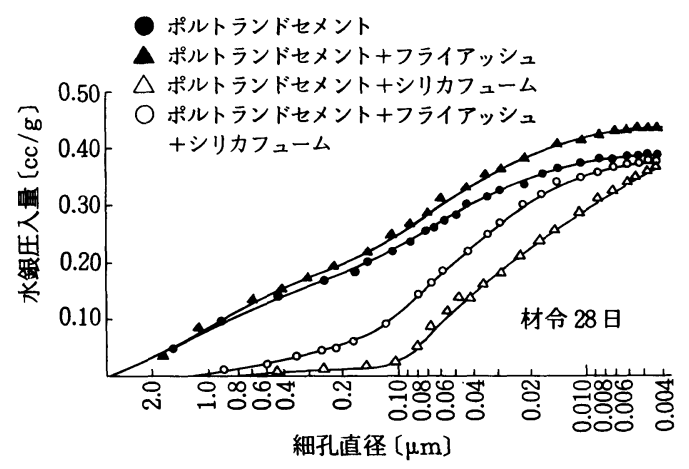

图 7 水銀圧入法によるペースト細孔径分布 ${ }^{21)}$

その細孔径の空隙が多いととを示し, 圧入される水銀 量が多いほど細孔容積が大きいととを示す。シリカフ ュームを混入すると， $0.1 \mu \mathrm{m}$ 以上の大きな細孔径の量 が少なく、微小な細孔が多くなることがわかる。

図8 は, 養生条件 $\left(20^{\circ} \mathrm{C}\right.$ 水中, $70^{\circ} \mathrm{C}$ 蒸気中, また は $120 \sim 180^{\circ} \mathrm{C}$ 高温高圧蒸気中に, 表記の時間セメ ントペーストを静置していた場合）の相違がシリカフ ュームを混入したセメントペーストの細孔容積に及ぼ

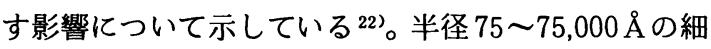
孔量は, 養生温度が $20^{\circ} \mathrm{C}$ 場合, シリカフューム混入 量が多く, 標準養生材令 $\left(20^{\circ} \mathrm{C}\right.$ 水中に静置しておく時 間)の長いものほど小さい。また高温高圧蒸気養生(オ 一トクレーブ養生)した場合, シリカフューム無混入 の場合は, 細孔量が多くなり, オートクレーブ養生温 度上昇に伴って増加するのに対し, シリカフューム混 


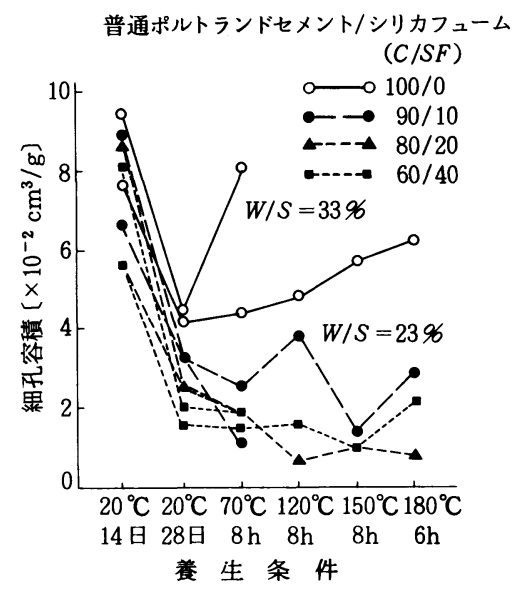

因 8 養生条件の相逞による細孔容積の変化 ${ }^{22}$

入の場合は, 細孔量が小さく, 養生温度による差も小 さくなっており，組織の粗大化はほとんど起てってい ない。同様な結果は長滝ら ${ }^{3,23)}$ あ得ている。

(2) 圧縮強度図 9 は, モルタルの圧縮強度とシ リカフュームのセメントに対する置換率，材令および 養生条件との関係を示している ${ }^{3,23)}$ 。置換率 30\%まで は置換率が増大するほど圧縮強度は増大し, 標準養生 (20 ${ }^{\circ} \mathrm{C}$ 水中) した場合, 置換率 15 30\%, 材令 28 日で $100 \mathrm{MPa}$ 達している。置換率 $30 \%$ で $80^{\circ} \mathrm{C}$ で蒸気養生 した場合の圧縮強度は材令 1 日で $100 \mathrm{MPa}$ が得られ， シリカフューム無混入の場合の約 2 倍となっている。 また, オートクレーブ養生した場合のシリカフューム モルタルの圧縮強度はオートクレーブ養生直後, シリ カフューム無混入の場合の約 1.4 倍の $140 \mathrm{MPa}$ が得ら
れている。てのような結果となったのは図8からあ明 らかなように，シリカフュームを混入することにより 細孔容積が小さくなり，緻密になるためである。また Bache $^{12)}$ は, 図4に示すように, シリカフュームと高 性能減水剂を用い, 水結合材比が $0.13 \sim 0.18$ の場合, マイクロフィラー効果によって, シリカフュームがセ メント粒子間を充坥するため緻密な組織となって 120 〜 $270 \mathrm{MPa}$ の圧縮強度が得られたと報告している。㐮ら も, 強度に及ぼす超微粒子の効果および微細組織につ いて詳細な検討を行っている。

（3）ヤング係数, 乾燥収縮㧍よびクリープシリ カフュームコンクリートのヤング係数は, シリカ無混 入の場合と比べ流動性が悪いため，一般にセメントペ 一スト量が多くなり，その分変形しやすくなるため多 少小さい3。コンクリートの乾燥収縮はひびわれの原 因となるため耐久性上問題となるが，シリカフューム

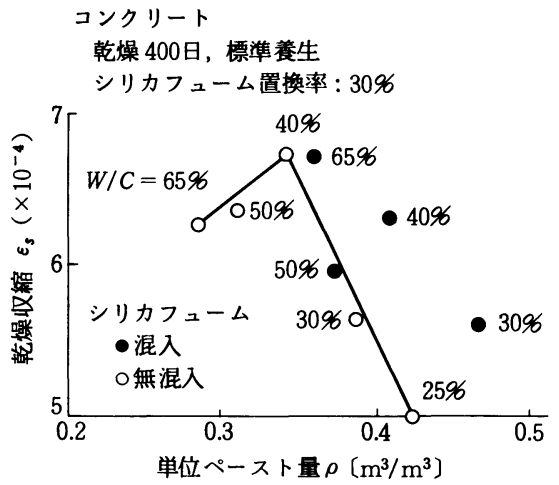

図 10 各種水セメント比のコンクリートの乾燥収縮と単位ペ ースト量との関係 ${ }^{25)}$

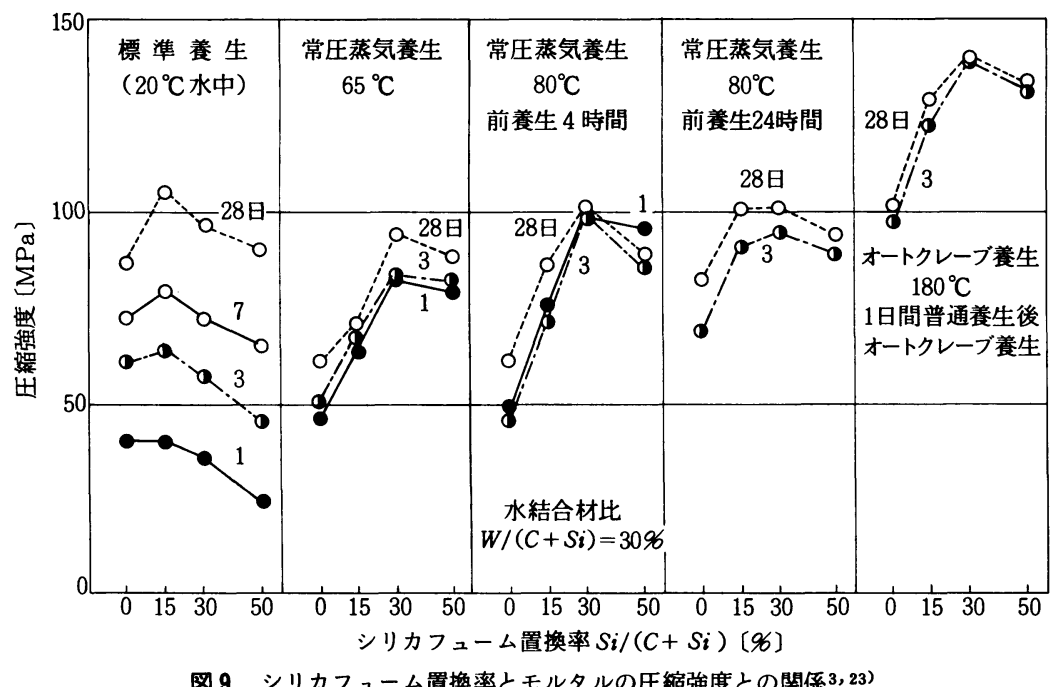

図 9 シリカフューム置換率とモルタルの圧縮強度との関係3, 23) 
コンクリートの乾燥収縮は, 図 10 亿示すように, 無 混入の場合よりコンクリート $1 \mathrm{~m}^{3}$ 当りのセメントペー スト量が多いにあかかわらず, 同一水結合材比におい て小さくなっている。シリカフュームを混入するてと により, 同一水結合材比において, 細孔容積が減少す るとともに微細な細孔の割合が多くなり, 強度も増大 する。そのため, 毛細管張力は大となり, 収縮力は増 大するので，乙の点からは収縮しやすいということに なるが, 同時に, 組織が緻密になるほど強度も増大す るため, この面からは変形しにくいということになり, 毛細管張力の増大ほどには収縮は増大しない3)。すな わち, 乾燥収縮は収縮力の大きさと変形のしやすさの 程度との両者の兼ね合いによって決まる。クリープは, 図11に示すように, シリカフュームを混入した場合の ほうが, 同一圧縮強度において, 空中で乾燥した場合 大きく, 水中環境下では, 無混入の場合之同程度であ る。乾燥した場合, 載荷応力以外に毛細管張力による 応力が作用しているのに，ての応力の大きさを明確に 知ることが困難であるため, 無視して単位応力当りの クリープ(単位クリープ)を計算している。そのため, 毛細管張力の発生が大きいシリカフュームコンクリー 卜の場合、クリープが大きいという結果になる。

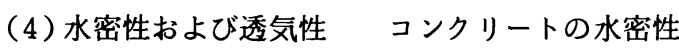
は, シリカフュームを混入するととにより著しく改善 され, 特に $\mathrm{Gj} \phi \mathrm{rv}^{27)}$ は, 貧配合の場合に効果が大きい と報告している。また長滰ら ${ }^{28}$ はコンクリートの透気 性に関し, 図 12 亿示すように, シリカフューム置換率 が増大するほど透気係数は小さくなると報告している。

（5）耐久性寒冷地における凍結・融解のくり返 しに対する抵抗性である耐凍害性に関する研究は比較 的多い。しかし, シリカフュームを混入するてとによ り耐凍害性は改善されるとするあのと 2,27), シリカフュ 一ム置換率が20～30\%になると著しく低下するとする あのがある ${ }^{1,29)}$ 。大和ら ${ }^{29}$ は, 図 13 亿示すように, 置 換率20〜30\%に打いては, 空気量 $4 \%$, 水セメント比 $\mathrm{W} / \mathrm{C}=0.5$ の $\mathrm{AE}$ コンクリートでさえ耐凍害性が低下 したと述べている。しかし, W/C = 0.25 の場合は, シリカフューム混入の有無に関係なく, non-AEコン クリートでさえ良好な耐凍害性を示したと報告してい る。したがって, シリカフュームコンクリートの耐凍 害性を確保するためには, 空気量を無混入コンクリー トの場合より幾分多くしたAEコンクリートとするて とが必要と思われる。

（6）アルカリ骨材反応抑制効果 アルカリ骨材反 応は, ある種の反応性骨材 (砕石) とセメントとが反応

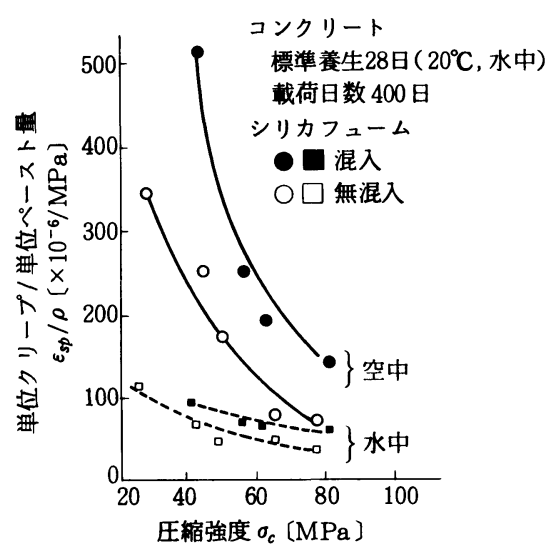

図 11 単位クリープと圧縮強度との関係 ${ }^{25)}$

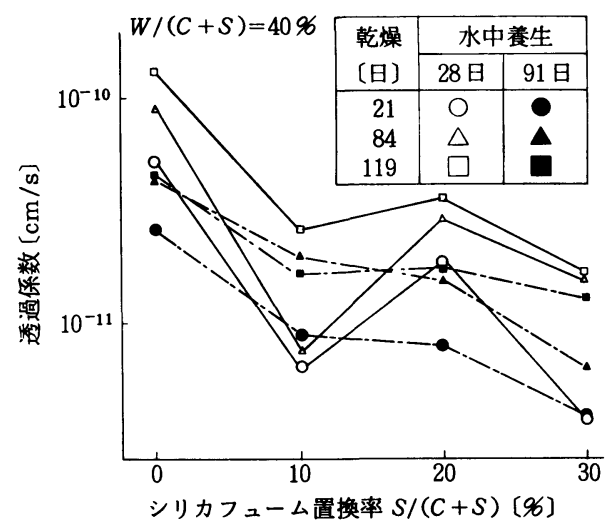

図12透気係数に及ぼすシリカフューム置換率の影䈏 ${ }^{28)}$

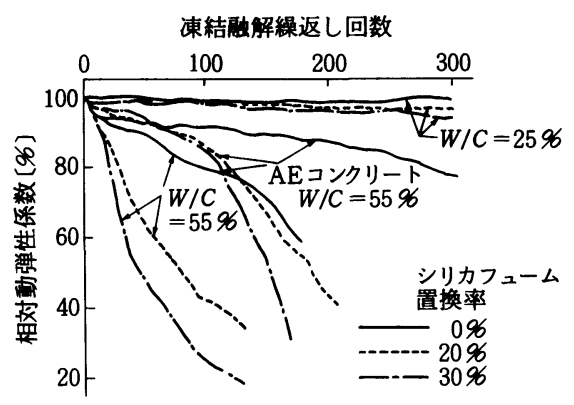

因 13 凍結融解試験結果 29 )

し，膨張するてとによって, コンクリートに膨張ひび われを発生させるので最近社会的にも問題となってい るが, アイスランドでは, シリカフューム置換率 $5 \%$ で, アルカリ・シリカ反応 (アルカリ骨材反応の一種) によるコンクリート構造物の劣化の問題がほとんどな くなったとしているが, 川村ら ${ }^{30}$ は, は, シリカフューム置換率が $5 \sim 10 \%$ 場合, かえっ て膨張量が無混入の場合より増大することがあるとと 


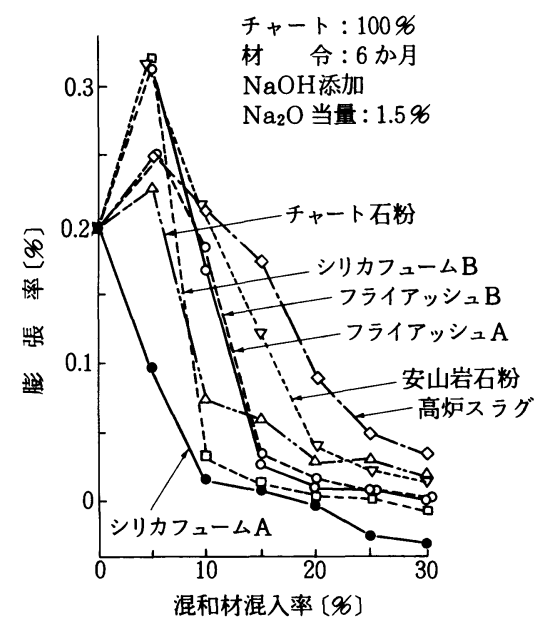

因 14 チャートモルタルの各種混和材による膨張抑制効果 ${ }^{31)}$

を報告している。森野ら 31 む, 図 14 亿示すようにシリ カフュームに限らず他の混和材を用いた場合も， $5 \%$ 程度の置換率では, かえって膨張量が増大しうるてと があるが，20\%程度以上置換することによって, 膨張 量を大幅に低減できると述べている。

\section{参 考 文 献}

1) Malhotra, V.M. and G. G. Garette : Silica Fume Concrete - Properties, Applications and Limitations, Concrete International, 5, No.5, pp. 40 46, May (1983)

2) Jahren, P. : Use of Silica Fume in Concrete, Fly Ash, Silica Fume, Slag \& Other Mineral By-Products in Concrete, ACI, SP-79, pp. 625 542 (1983)

3 ）長滝重義・米倉亜州夫：シリカフュームとコンクリート, コンクリート工学, 23 , No. 5, pp. 5〜15, May (1985)

4) 小林正几・笠井芳夫 : シリカフューム, セメント・コン クリート用混和材料, pp. 101 119, 技術書院 (1986)

5 ) Malhotra, V. M., V.S. Ramachandran, R. F. Feldman and Pierre-Claude Aïtcin: Condensed Silica Fume in Concrete, CRC PRESS (1988)

6 ）河野 清：産業副産物の利用に関する国際会議より一 シリカフュームを中心に，セメント・コンクリート， No. 447 , pp. $52 \sim 58$ (1984)

7) 河野 清: フライアッシュ, シリカフューム, スラグな どのコンクリートへの利用に関する第 2 回国際会議の概要, セメント・コンクリート, No.474, pp. 58〜65 (1986)

8 ) Malhotra, V. M.Edit. : Fly Ash, Silica Fume, Slag \& Other Mineral By-Products in Concrete, ACI, SP79, Vol. I, II (1983)

9) Malhotra, V. M. Edit. : Fly Ash, Silica Fume, Slag \& Other Mineral By-Products in Concrete, ACI, SP91 (1986)

\section{4. 用途}

シリカフュームは, コンクリートの高強度化, 耐久 性の向上, アルカリ骨材反応の抑制, ブリージングの 減少, 分離低減, 織維分散の促進等, 多くの点でコン クリートの品質改善に役立つと期待されるため, 広い 分野で活用されるようになってきている。コンクリー 卜構造物への使用例としては, 北海油田の石油掘削リ グ, 高層ビル, 橋, 河川水路, 鋼織維吹き付けコンク リート等がある3゙。

\section{5. おわりに}

ての度, 粉体工学会よりシリカフュームのコンクリ 一トへの利用について解説記事を書くようにとの依頼 を受け, 光栄に思うとともに，粉体に対する知識があ まりない状態で独断之偏見を述べることになるのでは ないかと抵抗を感じた。御批評，御教示を睗るととあ に，いくらかであ参考にしていただければ幸いである。

最後に，参考にさせていただいた多くの資料の研究 者各位に厚く御礼申し上げる。

10）内川 浩：混合セメントの水和および構造形成に及ぼす 混和材の効果, セメント・コンクリート, No. 483, pp. 15 23 (1987)

11）セメント協会海洋開発専門委員会 : シリカフュームを 用いたコンクリートに関する調査報告, M-2,（1986）

12) Bache, H. H. : Densified Cement/Ultra-Fine Particle - Based Materials, presented at the Second International Conference on Superplasticizers in Concrete, Ottawa, Canada (June 1981)

13) Sellevold, E. J. and F.F. Radjy : Condensed Silica Fume(Microsilica) in Concrete; Water Demand and Strenght Development, ACI, SP-79, Vol.II, pp. 677 $\sim 694$ (1983)

14）佐藤 健：セメント・混和材, 特集: 先端技術とコンク リート技術，コンクリート工学， $24 ，$ No. 3, pp. 10〜14 (1986)

15）营 蔽, 声田公伸, 䛀井悦郎：超微粉を用いた高強度セ メントの硬化と破壊，セメント・コンクリート，No. 495 pp. 20 24 (May 1988)

16) Bürge, T. A. : High Strength Lightweight Concrete with Condensed Silica Fume, ACI, SP-79, pp. 731 745 (1983)

17) Mehta, P. K. : Pozzolanic and Cementitious Byproducts as Mineral Admixture for Concrete - A Critical Review, ACI, SP-79, p. 43 (1983)

18）内川 浩: 混合セメントの水和抢よび構造形成に及ほ 
す混合材の効果(その 2)，セメント・コンクリート，No. 484 (1987)

19) Grutzeck, M.W., S. Atkinson and D. M. Roy : Mechanism of Hydration of Condensed Silica Fume in Calcium Hydroxide Solutions, ACI, SP-79, pp. $643 \sim 664$ (1983)

20) I. Meland : Influence of Condensed Silica Fume and Fly Ash on the Heat Evolution in Cement Pastes, ACI, SP-79, pp. 665 676 (1983)

21) Mehta, P. K. and $\phi$. E. Gj申rv : Properties of Portland Cement Concrete Containing Fly Ash and Condensed Silica Fume, Cement and Concrete Research, 12, pp. 587 595 (1982)

22）小野啓一・浅賀喜与志・大門正機：シリカフュームを 含むセメントペースト硬化体の細孔構造と乾燥収縮, 七 メント技術年報，40，pp. 63～66（1986）

23）長滝重義・米倉亜州夫・横田 弘：高温養生したコン クリートの力学的性状に及ぼす活性シリカの効果, セメ ント・コンクリート, No. 387, pp. 8〜15 (1979)

24）芦田公伸 - 袁 厳・伏井康人・坂井悦郎：超微粉を用 いた高強度セメントの硬化と破壊機構, コンクリートエ 学年次論文報告集, 9, No. 1, pp. 39 44 (1987)
25）米倉西州夫・伊藤祐二：活性シリカを用いたコンクリ 一トの乾燥収縮およびクリープに関する研究, 第 4 回コ ンクリート工学年次講演論文集, pp. 205 208 (1982)

26）長滝重義・米倉亜州夫：コンクリートの乾燥収縮抢よ びクリープの機構に関する考察, コンクリート工学, 20, No. 12, pp. 85 95 (1982)

27) Gj申rv, $\phi$. E. : Durability of Concrete Containing Condesed Silica Fume, ACI, SP-79, Vol. II, pp. 695 708 (1983)

28) Nagataki, S. and I. Ujike : Air Permeability of Concretes Mixed with Fly Ash and Condensed Silica Fume, ACI, SP-91, pp. 1049 1068 (1986)

29）添田政司・江本幸雄・辰本朋子・大和竹史：コンクリ ートの諸性質に及ぼすシリカフュームの影響, 第 7 回コ ンクリート工学年次講演会論文集, pp. 205 208 (1985)

30）川村満紀・竹本邦夫・枷場重正：シリカフュームのア ルカリ・シリカ膨張に及ばす影響, セメント・コンクリ 一ト, No. 469, pp. 29 35 (1986)

31）森野奎二・柴田国久・岩月栄治：シリカフューム, 高 炉スラグ粉末のAAR膨張抑制効果について, コンクリー 卜工学年次論文集, 9, No. 1, pp. 81 86 (1987)

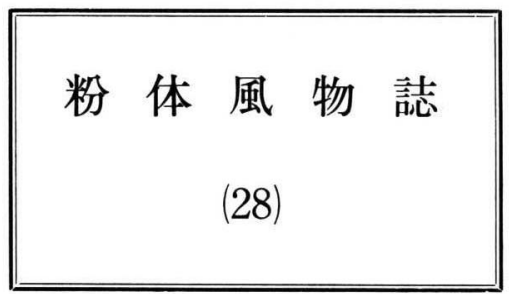

\section{トルコの火薬袋}

図はトルュ・イスタンブールのトプ・カプ宮殿博物 館の火薬袋を示す。このような入れ物に入れて腰に着 けたものと思われる。

1966年，ノーベルによりニトログリセリンをけい藻 土に吸収させると安全化できることを発見し，ダイナ マイトが発明され, 高性能火薬の製造工業が急速に発 達した。19世紀末にフェノールの二トロ化で得られる ピクリン酸が強力な爆薬となることが発見された。日 本では“下瀬火薬”の名でつくられ，1905年の日本海 海戦の戦勝の原因となった。第 1 次世界大戦, 第 2 次 世界大戦でも主としてTNTとピクリン酸が用いら れ，ーベルの意志とは逆についに原子爆弾まで作ら れる破目に陥った。

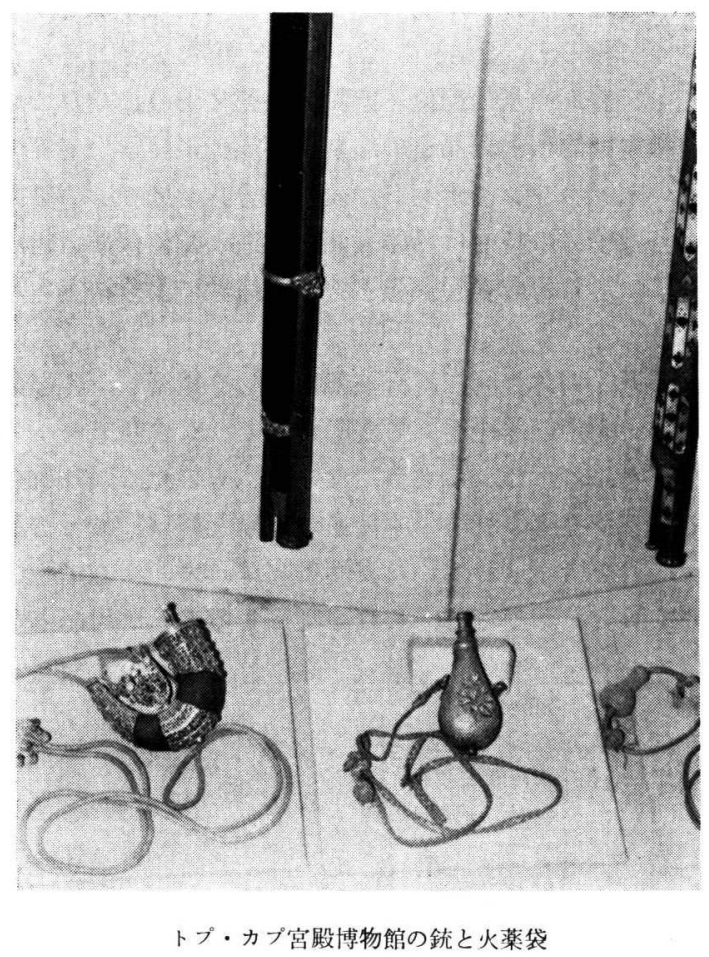

（奥田 聡） 